\title{
Appendix: Response to Hartshorne's "Peirce and Religion"
}

PROFESSOR HARTSHORNE'S ESSAY is a remarkable summary of his contribution to recent philosophical theology and an illuminating account of the way Peirce has influenced his thinking in the subject. Beyond that, Hartshorne's critical evaluation of Peirce's philosophical approach to God is a valuable contribution to the understanding of pragmaticism.

For my part here I would like to accomplish three goals: first, to react to some selected remarks of Hartshorne's in his evaluation of Peirce's reflections on God (his essay is much too rich for me to deal with all the points it makes); second, to select two aspects of Peirce's thought for further development; and, finally, to offer my own assessment of Peirce's accomplishment in reasoning about God. I hope to achieve these goals per modum unius, that is, without breaking them out separately.

In the first place, then, let me say immediately that I agree almost completely with Hartshorne's assessment of Peirce's strengths and weaknesses. I thoroughly agree that Peirce might indeed be characterized as between two worlds-the world of classical theism (from which he moved away) and the world of process theism (at which he had not arrived). Peirce's philosophical theology is neither Aquinas's nor Hartshorne's. This fact will probably endear him to neither of these schools. Whether Peirce's shortcomings in theological reflection are properly remedied in the ways Hartshorne suggests I leave to the reader to decide. That some of Peirce's reflections on God need clarification, if not correction, I think will become evident as we proceed, if it is not already so.

As is well-known, for pedagogical reasons Scholastics frequently

This essay under the title "Response to Hartshorne" and Professor Hartshorne's paper appear in Peirce and Contemporary Thought: Philosophical Inquiries, ed. Kenneth Laine Ketner, American Philosophy Series No. 1 (New York: Fordham University Press, 1995). 
divided their treatises on God into two parts: namely, into the two questions "An sit Deus?" and "Quid sit Deus?" Ultimately, of course, the two questions cannot be kept apart, because the answer to the first depends upon the answer to the second. Still, I shall use that division as a convenient way of lining up some of Hartshorne's important remarks about Peirce. My impression is that Hartshorne would give Peirce rather higher marks for his treatment of the first question-that is, "Is there a God?" - than for his treatment of the second-"What is God?" I would like to consider Peirce's proof more closely to show how, in fact, his answer to the question of whether there is a God is connected to his answer to the question of what God is.

Now, to begin with Hartshorne's positive assessment of Peirce, I take it that he thinks that two of Peirce's most important contributions to philosophical theology are $(a)$ his emphasis on the fact that human beings have access to God's reality in ways other than conceptualization and ratiocination; and $(b)$ his recognition that all traditional proofs for God-ontological and cosmological-contribute something important to the issue (see, for example, 6.504); in the case of the ontological argument, that either God exists necessarily or else the very notion of God is self-contradictory and incoherent; in the case of the cosmological argument, that the experience of the world shows God's existence to be neither selfcontradictory nor incoherent. I agree completely with this assessment.

Peirce constantly insisted that religious belief is instinctive (see, for example, 6.497-500). It is a matter of sentiment, of the heart rather than the head. He thought that mankind can perceive God directly and, in fact, if mankind cannot so perceive God, God cannot be known at all. It is this instinctive belief that is at the heart of the first of Peirce's "proofs"- -from musement or free contemplation. Moreover, it is well-known that the pragmatic movement, following Peirce's lead, set out to recover experience from the narrow and arid thing it had been made to be by certain forms of empiricism. For Peirce, experience is so rich that it is the sole source of whatever man knows-including God (see, for example, 6.492-493). Hence, for Peirce, some form of religious experience is necessary (although not sufficient) for any rational belief in God.

Peirce frequently remarked that all reasoning about religious 
matters must be unsound and that all study of them must be sordid and narrow. Nonetheless, Peirce did reason about God, and he did undertake a serious study of religious issues. He did so because he considered Reason to be a development and extension of Instinct. One might say he considered Reason to be the specifically human instinct with which evolution equipped mankind to deal with the as-yet-unfamiliar. But instinctive belief in God is indubitable as long as that belief is left sufficiently vague; but once questions arise which call for attempts at precision which in turn open the instinctive belief to doubt, then only Reason can serve the need, albeit in a halting way. For a pragmatist, furthermore, no belief should be fixed merely by tenacity or authority; doubts and questions must be explored by Reason.

For Hartshorne's second major commendatory point-Peirce's proofs for God's reality. I suggest we rely on Peirce's 1908 Hibbert Journal article (6.452-491), since it represents his mature thought on this matter. There Peirce offered us three nested arguments for God's reality (not God's existence, since existence for Peirce is the category of contingent matter of fact, of physical objects interacting in space and time-and to apply this category to God would, in Peirce's eyes, be making God simply another object among objects). These arguments are nested, in that the third argument includes within it the second and the first; the second includes within it the first (in just that way in which the categories are related). The first argument is the so-called Humble Argument based on the exercise of musement or free contemplation of the three Universes of Experience (the Possible, the Actual, and the Necessary). The point of this exercise is that our instinctive belief in God will assert itself on the occasion of considering the beauty and coherence of each of the Universes and of their interconnections. Although the Humble Argument issues in the hypothesis of God, the second nested argument, the Neglected Argument, shows that this hypothesis is the God-hypothesis, that is, that the reality so postulated is not merely finite and contingent, but infinite and necessary. Writing to William James in 1905 Peirce remarked:

The God of my theism is not finite. That won't do at all. For to begin with, existence is reaction, and therefore no existent can be clear supreme .... In the next place, anthropomorphism for me 
implies above all that the true Ideal is a living power, which is a variation of the ontological proof. . . That is, the esthetic ideal, that which we all love and adore, the altogether admirable, has, as ideal, necessarily a mode of being to be called living. Because our ideas of the infinite are necessarily extremely vague and become contradictory the moment we attempt to make them precise. But still they are not utterly unmeaning, though they can only be interpreted in our religious adoration and the consequent effects upon conduct. (8.262)

I would point out (1) that this formulation of the ontological argument in terms of a real infinite Ideal might also have been articulated in terms of the moral Ideal of Goodness or the logical Ideal of Truth; (2) that it is a step away from the classical formulation of the argument toward what I would call a pragmatist variation, since it is not merely in the conceptual order but in the conceptual order insofar as it is linked to human conduct. I think Peirce chose the esthetic formulation as more readily seen to be available in musement.

The third nested argument situates the God-hypothesis within the logic of rational inquiry and so puts it immediately in the context of human conduct. Again, I take this to be a move away from the classical formulation of the cosmological argument insofar as it does not move merely from contingency to necessity by effect to cause, but rather from human thinking, willing, and feeling to their adequate sufficient reason, which is in turn a living ideal of that sort of human behavior. Completely to appreciate what Peirce understood by this third argument from conduct (hence, from the world to God - the cosmological move with a pragmatist twist!) one would have to know his doctrine concerning the normative sciences, his understanding of scientific method, and the hierarchy of the sciences. In brief, unless God were a reality, a non-fictional ideal, with real living power, all human inquiry would be meaningless. Conversely, once that Ideal is acknowledged, how we behave is affected.

Perhaps now is the time to make our transition to the second question posed by the Scholastics in the philosophy of God: namely, "Quid sit Deus?" Far and away Peirce's favorite characterization of God is "creator." Peirce began the Hibbert Journal article by defining God as Ens necessarium, but as Donna Orange pointed 
out in Peirce's Conception of God, ${ }^{1}$ this is the only place that Peirce explicitly used this attribute of God. She also shrewdly pointed out that the entire set of nested arguments can be read as an attempt to bring the conception of God to the third degree of pragmatic clarity as achieved through the use of the pragmatic maxim. That maxim would take God to be above all creator. Peirce wrote: "God is the definable proper name, signifying Ens necessarium; in my belief Really Creator of all three Universes of Experience" (6.452). Note that he immediately qualified Ens necessarium in terms of creator. No doubt, Peirce used the term Ens necessarium to elicit a connection with both the Anselmian and the Aquinate argument from contingency (the third way). I suspect, too, that he had in mind Royce's Absolute, which he conceded might be an appropriate abstract characterization of God but which was empty since it had no implications for human conduct. If the Absolute as Ens necessarium is given the pragmatic interpretation of super-order, of which order and uniformity of the created universes are but particular varieties, then Peirce thought he could argue from the predictability that general laws governing matters-of-fact bring, to the need for such a super-order. The growth of the universe from chaos to order is what Peirce meant by the growth of concrete reasonableness and is probably what he meant by the pragmatic import of Ens necessarium. In effect, if the universe is intelligible, as science assumes that it is, it must exhibit generality, and the source of that generality must be necessary reasonableness.

This brings us to a central unclarity or waffling in Peirce's philosophy of God. The issue comes down to this: Is "God" for Peirce God or Reason? Is the growth of concrete reasonableness in the universe (Peirce's summum bonum) what he means by "God," or is this the sign of God? In a word, is God immanent or transcendent? Is he both? If so, in what sense or senses? Donna Orange concluded, in her study of Peirce's conception of God, "these texts . . . confirm my suspicion that Peirce's theism amounted to a belief that certain inescapable beliefs we hold can be expressed in religious language when such expression is appropriate or necessary for worship and the conduct of life."2

Hartshorne has astutely pointed out that because of Peirce's insistence on the role of experience in our understanding of God, some form of anthropomorphism is to be expected and that the 
only real issue is to find which analogies are fitting and properthat is, to find which predicates of God Peirce would characterize as "less false." In this regard Hartshorne is completely correct, in my opinion. Again, he is right in holding that the merely negative attributes alone will not do. They do serve a purpose, however, and cannot simply be dismissed as "abstractions," since they do set certain boundary limits beyond which predicates are unacceptable and perhaps even "vicious," to use Hartshorne's expression. Still, "negative theology," when coupled with "less false" positive attributes, is useful, even necessary, for theological discourse. Peirce seemed to think that the classical predicates-such as infinite, omniscient, omnipotent, creator-fit the bill better than some of those suggested by William James, for example.

Hartshorne approves of Peirce's attributing growth and change in some sense to God. But this is an area of Peirce's thought which needs clarification. It would perhaps be helpful to quote a passage where Peirce made such an assertion to see the extent to which he hesitated in this matter:

The hypothesis of God is a peculiar one, in that it supposes an infinitely incomprehensible object, although every hypothesis, as such, supposes its object to be truly conceived in the hypothesis. This leaves the hypothesis but one way of understanding itself; namely, as vague yet as true so far as it is definite, and as continually tending to define itself more and more, and without limit. The hypothesis, being thus itself inevitably subject to the law of growth, appears in its vagueness to represent God as so, albeit this is directly contradicted in the hypothesis from its very first phase. But this apparent attribution of growth to God, since it is ineradicable from the hypothesis, cannot, according to the hypothesis, be flatly false. Its implications concerning the Universes will be maintained in the hypothesis, while its implications concerning God will be partly disavowed, and yet be held to be less false than their denial would be. Thus the hypothesis will lead to our thinking of features of each Universe as purposed; and this will stand or fall with the hypothesis. Yet a purpose essentially involves growth, and so cannot be attributed to God. Still it will, according to the hypothesis, be less false to speak so than to represent God as purposeless. (6.466; emphasis added)

This paragraph deserves careful study and requires some close analysis to determine just what is being maintained and whether 
it is defensible. In the first place, it is evident that Peirce hesitated about attributing growth to God. He was still enough under the influence of the classical notion of God as immutable because infinitely perfect-that is, as possessing every perfection in a supereminent way (the classical understanding of "pure act")—that he thought that the hypothesis of God as Ens necessarium "directly contradicts" the notion of change and growth in God. What I find curious is the argument that because the hypothesis of God is vague but true insofar as it is definite, and because that hypothesis tends to define itself more and more, "it" (the hypothesis? God?) is subject to growth. Certainly, it is true that the hypothesis in its expression and articulation grows. I fail to see, however, that it follows necessarily that what is true of the hypothesis as expressed is true also of what the hypothesis expresses. Such an error would be the same as attributing to what is measured the properties of the measure. It might be urged that Peirce really meant to attribute growth (and so purpose) to the created Universes, and that insofar as those Universes are a sign of God (as a great poem is a sign of the poet), in some sense something like growth can be attributed to God, but not literally-unless, of course, Peirce meant that in the case of God and the Universes, sign and signified are identified. Again, it seems unlikely to me that Peirce would hold that, because then the notion of sign becomes vacuous. It is more likely that Peirce held some partial identity of God and the Universes, a point to which I will return shortly.

In very abstract terms one can ask whether God for Peirce is transcendent or immanent. No doubt, Peirce thought that God is not merely immanent. God is immanent in the sense that, as creator, $\mathrm{He}$ is a living power present to (even if not identical with) the created Universes. But God is, after all, creator of the Universes (or at least of some of them!): He is their source, and so cannot be simply identical with them. The Universes as created depend upon God and so do not exhaust God's reality. Again, in Peirce's version of the ontological argument, God is characterized as the Ideal (esthetic, moral, logical) and so transcends any instance of beauty, goodness, or truth. The question is whether this transcendence means that God is outside and beyond the Universes of experience or whether God is at least partially identified with those Universes. Hartshorne put his finger on the problem when he asked whether 
or not, for Peirce, the categories apply to God. Hartshorne rightly points out that you will find indications that seem to support each of these views. It seems to me that Peirce should maintain that the categories apply to God (since they are strictly universal) in some way or other. The real question is: How?

The hesitation in this matter can be seen in the Hibbert Journal article when Peirce, laying out the Neglected Argument, described the activity of musement as "that course of meditation upon the three Universes which gives birth to the hypothesis and ultimately to the belief that they, or at any rate two of the three, have a Creator independent of them ..." (6.483; emphasis added). It seems clear from the context that Peirce thought God to be creator of, and so other than, the Universes of Possibility and Actuality, since neither of these alone accounts for reality-possibilities are merely what may be, while actuals are a contingent matter of physical fact. But is God identical with the third Universe? Is God Reason, Mind, Concrete Reasonableness? Or is God perhaps the totality or wholeness of Reason as penetrating actuals and as source of possibilities? Peirce might argue that the pragmatic conception of "God" is the ideal wholeness of Reason which alone could be fully real and so in that sense could alone be transcendent creator.

Hartshorne also pointed out in his essay what he takes to be a "real blunder" on Peirce's part, in that he held that only our faults or defects distinguish us from one another. This might also account for his difficulty in relating God's transcendence and immanence. If Peirce had no positive account of individual distinctness, he could hardly think of God as a distinct positive individual reality transcending (and so standing outside of) the three Universes. Thus, for example, Peirce spoke of God as Absolute First (Alpha) and Absolute Second (Omega). Must he also have said that God is all the rest in-between-or at least the wholeness of the inbetween? Or might he have said that God is also Absolute Third outside the world and continuously creating and conserving it. The analogy here is that of an hyperbola defined by its asymptotes and generated by an algebraic function. This, then, could be read as a distinct individual reality (distinct from the created arguments). I am not at all sure about what I have just suggested, but raise it more as a question. I would like to say, however, that attempts have been made to use Peirce's principles to construct a positive account 
of the self and of the subject. ${ }^{3}$ Hence, I am not sure that this was so much a blunder as simply an omission, although we still might call such an omission a blunder. At any rate, this raises the correlative question of whether Peirce exaggerated the role of continuity in identifying (or seeming to identify) it with reality. It is one thing to maintain that nothing can be real without partaking in continuity; it is another to claim that continuity exhausts reality. The latter claim would, of course, eliminate the category of Secondness from reality - a charge often brought against Peirce by his critics, but something which Peirce, at his best at least, would not hold.

The final issue I would like to raise is whether or not for Peirce creation is free. Hartshorne makes a distinction between creation's being free in specification and being necessary in exercise. Hence, this particular world is radically contingent and so it need not have been, but the creation of some world or other is necessary, since, if God is creator at all, he is creator necessarily. I tend to think that Peirce would be in substantial agreement with that, while I would not. I would prefer to say that any particular instantiation of the possible is contingent, but some actual entity must be necessary in order for anything else to be possible at all. Since there is no realm of entities called "possibles" which have ontological status independent of the actual and the necessary being, God creates freely, not necessarily, from all eternity. My question is whether such freedom, as Hartshorne allows God in creating, is sufficient to do justice to God's transcendence. Must there not also be, with respect to creation, freedom of exercise; that is, must not God be free not to create any world, where "any" has both the collective and the distributive sense? Isn't this required in order for God to be completely independent of the created world? Perhaps the difficulty here is a certain ambiguity in the term "necessary." The term is used in several ways: first, in the usual sense of "causal connection," according to which, when the necessary and sufficient conditions for an event are present, the event happens necessarily-more exactly, when those conditions for the event are fulfilled, the event itself is virtually unconditioned (necessary in that sense); second, in the statistical sense of "what is logically inevitable" given an unlimited long run. Each of these senses of "necessary" is hypothetical, not absolute. That is, each requires only that there be in 
fact, not that there must be, some actual world or other. There is yet another sense of "necessary"- a reality which simply is unconditionally. It simply has no conditions at all. This is the classical notion of God's necessity. Is this Peirce's sense? Again, I think there is hesitation and waffling here in the same way, and for the same reason, that there is hesitation and waffling about how to understand God's transcendence.

I hope that these reflections, prompted by Hartshorne's essay, will encourage interest in Peirce's religious philosophy in such a way as to clarify further what Peirce himself held, and more important, to show how his reflections might help us to a deeper understanding of that Ideal whose living power bears upon human conduct.

\section{NOTES}

1. Donna M. Orange, Peirce's Conception of God: A Developmental Study, Peirce Studies 2 (Lubbock, Tex.: Institute for Studies in Pragmaticism, 1984).

2. Ibid., pp. 81-82.

3. See Stanley Harrison, "Man's Glassy Essence: An Attempt to Construct a Theory of Person Based on the writings of Charles Sanders Peirce," Ph. D. Diss., Fordham University, 1971; and Vincent M. Colapietro, Peirce's Approach to the Self: A Semiotic Perspective on Human Subjectivity (Albany: State University of New York, 1989). 